\title{
The effect of substitution of sodium chloride with potassium chloride on the physicochemical, microbiological, and sensory properties of Halloumi cheese
}

\author{
R. Kamleh, ${ }^{*}$ A. Olabi, $\dagger^{1}$ I. Toufeili, $\dagger$ N. E. O. Najm, $\dagger$ T. Younis, ${ }^{*}$ and R. Ajib* \\ *Environmental Health Department, Faculty of Health Sciences, University of Beirut, Riad El Solh 1107 2020, Beirut, Lebanon \\ †Nutrition and Food Sciences Department, Faculty of Agricultural and Food Sciences, American University of Beirut, Riad El Solh 11072020 , \\ Beirut, Lebanon
}

\begin{abstract}
This study investigated the effect of salt reduction and partial replacement with $\mathrm{KCl}$ on the microbiological and sensory characteristics of fresh and matured Halloumi cheese. Halloumi samples were matured for $8 \mathrm{wk}$ and moisture, fat, protein, $\mathrm{pH}$, lactic acid, sodium, and potassium contents determined. Instrumental textural characteristics of the samples were measured using a texture analyzer. Microbiological analyses included counts of total bacteria, lactic acid bacteria, yeasts and molds, total coliforms, and psychrophilic bacteria. Descriptive sensory analysis was carried out by a 9 -member panel, and acceptability testing was conducted with 72 panelists. Salt treatment had a significant effect on the $\mathrm{pH}$, sodium, and potassium contents of the cheeses, whereas age by salt treatment interaction had a significant effect on the $\mathrm{pH}$, lactic acid, and potassium contents of the samples. No major trends could be discerned from the texture profile analysis. All tested microorganisms increased with storage but in general did not differ between treatments and were, in certain instances, lower than levels reported in the literature for other cheeses. Descriptive analysis revealed a significant difference between salt treatments for bitterness, crumbliness, and moistness, whereas age of cheese was significant for saltiness and squeakiness. Salt treatment had no significant effect on any of the acceptability variables for all Halloumi samples.
\end{abstract}

Key words: Halloumi, potassium chloride, sensory, salt

\section{INTRODUCTION}

White brined cheeses are the most consumed group of cheeses in the eastern Mediterranean region and some neighboring countries (Alichanidis and Polychroniadou, 2008). Halloumi, the traditional cheese of Cyprus and a popular cheese in many countries of the region, including Lebanon, is one of the most well known cheeses

Received August 26, 2011.

Accepted October 8, 2011.

${ }^{1}$ Corresponding author: ammar.olabi@aub.edu.lb of this group, and it has gained increased popularity in recent years (Papademas, 2006; Kaminarides et al., 2007). Halloumi may be consumed fresh or stored in whey brine until it is matured. Salt plays an essential role in cheese manufacture: its main functions are taste and preservation. In terms of sensory characteristics, salt enhances other flavors and reduces the perception of bitterness, thus fulfilling determinant roles toward consumer satisfaction (Kilcast and Angus, 2007). Food manufacturers are therefore reluctant to reduce the amount of salt in their products if it results in a decline in profit generation due to reduced acceptability and safety of their products (Gibson et al., 2000; Brady, 2002). However, data from numerous studies have linked high salt or sodium intakes with elevated blood pressure (Doyle and Glass, 2010), which is the most substantial risk factor for cardiovascular disease (Gibson et al., 2000; Hannedouche et al., 2007). Reducing salt intake represents one of the most worthy objectives for advancing public health worldwide. In most developed countries, processed food contributes approximately 75 to $80 \%$ of total salt intake (Gibson et al., 2000; Kilcast and Angus, 2007). Thus, it is reasonable to target first the reduction of salt in processed foods.

Potassium represents the most frequent option as a feasible salt substitute (Kilcast and Angus, 2007). Numerous studies have shown that an increased intake of potassium in the diet can decrease the effect of sodiuminduced hypertension, decrease urinary calcium excretion, and thus potentially protect the skeletal mass (Karagözlü et al., 2008). Several studies have assessed the potential of potassium as a sodium substitute on cheese processing and storage quality, including Feta (Katsiari et al., 1997, 2000), Greek Kefalograviera (Katsiari et al., 1998, 2001), white salted cheese (AlOtaibi and Wilbey, 2006), Fynbo cheese (Sihufe et al., 2006), white pickled cheese (Karagözlü et al., 2008), and Halloumi (Ayyash and Shah, 2010, 2011b; Ayyash et al., 2011). However, no study has so far reported on the effect of salt reduction and partial replacement with $\mathrm{KCl}$ on the microbiological and sensory characteristics of fresh and matured Halloumi cheese. In addition, the 
Halloumi studies mentioned above used an 18\% (wt/ wt) brine solution that, regardless of the salt substitution level, results in considerable potassium intake that may not be feasible from a safety and public health perspective, especially for subjects with kidney disease or a family history of kidney disease. Accordingly, the objectives of this study were to determine the effect of $\mathrm{NaCl}$ substitution with $\mathrm{KCl}$, in lightly salted Halloumi, on the physicochemical, microbiological, and sensory properties of Halloumi cheese.

\section{MATERIALS AND METHODS}

\section{Cheese Production}

Halloumi cheese was made from pasteurized cow milk $\left(68^{\circ} \mathrm{C}, 30 \mathrm{~min}\right)$. The pasteurized milk was cooled to 38 $\pm 1^{\circ} \mathrm{C}$ and $\mathrm{CaCl}_{2}$ was added at $0.20 \%$. An appropriate volume of rennet was added and stirred. After $45 \mathrm{~min}$ of incubation, the coagulum was cut into grains of approximately $1 \mathrm{~cm}^{3}$. The curd pieces were left to rest for 5 min and then placed in square stainless steel molds lined with cheesecloth. The curd was pressed at 300 $\mathrm{kPa}$ for $15 \mathrm{~min}$ and then at $400 \mathrm{kPa}$ for $45 \mathrm{~min}$. Whey proteins were removed from the expelled whey by boiling in the presence of $0.5 \%$ citric acid at $95^{\circ} \mathrm{C}$ for 10 min. The pressed curd was cut into rectangular blocks $(10 \mathrm{~cm} \times 5 \mathrm{~cm} \times 3 \mathrm{~cm})$, which were then boiled for 30 to $35 \mathrm{~min}$ in the whey $\left(95^{\circ} \mathrm{C}\right)$ until they floated to the surface. The plasticized cheese blocks were removed from the whey, allowed to cool, and then folded. The folded Halloumi blocks were placed in plastic containers and covered with different pasteurized brines $(10 \%$ salt wt/wt): brine A $(100 \% \mathrm{NaCl})$, brine $\mathrm{B}(70 \% \mathrm{NaCl}$, $30 \% \mathrm{KCl})$, and brine $\mathrm{C}(50 \% \mathrm{NaCl}, 50 \% \mathrm{KCl})$. The salt substitution levels were chosen based on informal taste tests that were conducted to avoid choosing treatments with obvious and excessive bitterness. In addition, the $10 \%$ salt level was chosen because it is consistent with brined Halloumi that is sold fresh (8\%) in grocery stores and close to the packaged Halloumi sold in Lebanon, which is typically stored in $12 \%$ brine. Another consideration for choosing a lower salt concentration was to limit the intake of potassium in the KCl-substituted experimental samples for practical and health considerations. Cheese blocks were kept for $8 \mathrm{wk}$ at $4 \pm 1^{\circ} \mathrm{C}$ in the 3 brines.

\section{Chemical Analyses}

Representative samples were prepared according to AOAC (2000; method 920.11). The methods of the Association of Official Analytical Chemists (AOAC, 2000) were used to determine fat content (method 933.05), and protein content of the cheese (method 920.125) and moisture (method 948.12). The percentage of protein was calculated using the conversion factor 6.38 . . The percentage lactic acid in the cheese samples was determined according to AOAC (2000; method 920.124). pH values were determined using a digital $\mathrm{pH}$ meter (Hach, Loveland, CO); the electrode was directly inserted into the cheese sample (Papaioannou et al., 2007). Sodium and potassium content in cheeses were determined according the procedures of Demirci (1988), Faverotto (1990), and Karagözlü et al. (2008). All chemical analyses were performed in triplicate (3 samples of cheese at each sampling date).

\section{Instrumental Texture Analysis}

A texture analyzer (QTS25, Brookfield Engineering Labs, Middleboro, MA) equipped with a 38.1-mm cylindrical probe was used for the evaluation of the cheese textural properties. The speed of the cross-head was $60 \mathrm{~mm} / \mathrm{min}$ and the time elapsed between the first and second bite was $8 \mathrm{~s}$ after compressing the sample by $25 \%$ of its height $(0.5 \mathrm{~cm})$. Forty-five samples were tested (3 replicates $\times 3$ salt treatments $\times 5$ ages of cheese). Sample cubes $\left(2 \mathrm{~cm}^{3}\right)$ were taken from the center of the cheese blocks. After being cut, the samples were allowed to temper for $20 \mathrm{~min}$ and reach room temperature before testing. The test parameters were adhesiveness, chewiness, cohesiveness, hardness, and springiness.

\section{Microbiological Determinations}

Counts of total bacteria, lactic acid bacteria, yeasts and molds, total coliforms, and psychrophilic bacteria were conducted according to standard procedures: 20 $\mathrm{g}$ of cheese was blended with $180 \mathrm{~g}$ of sterile distilled water to obtain a homogeneous mixture, and further dilutions were conducted when necessary (Marshall, 1993). Incubation time and temperature for culture all mentioned microorganisms were set following the media manufacturer's instructions (Difco BBL, BD Diagnostics Systems, Heidelberg, Germany). Total bacterial counts (TBC) were enumerated by the pour-plate technique on plate count agar. The TBC was determined at 35 $\pm 1^{\circ} \mathrm{C}$ using an incubation period of $48 \mathrm{~h}$. Lactic acid bacteria were determined by the pour-plate technique using de Man, Rogosa, and Sharpe agar, and samples were incubated at $35^{\circ} \mathrm{C}$ for $72 \mathrm{~h}$. Yeasts and molds were determined using yeast and mold agar, and samples were incubated at $30^{\circ} \mathrm{C} \pm 1^{\circ} \mathrm{C}$ for $3 \mathrm{~d}$. Psychrophilic bacteria counts were determined at $10^{\circ} \mathrm{C}$ for 24 to 48 $\mathrm{h}$ by pour-plate technique using plate count agar. All microbiological analyses were performed in duplicate. 


\section{Descriptive Analysis}

The panel consisted of 9 members ( 6 females and 3 males) who were selected based on their willingness to participate and time availability. Panelists were mainly graduate students or staff in the Faculty of Health Sciences at the American University of Beirut. They were not informed about the details of the project; however, they were all familiar with Halloumi cheese and its characteristics. The study was approved by the Institutional Review Board of the American University of Beirut. The panelists were trained over three 1-h sessions. Different commercial and experimental samples were provided to the panelists during each training session. They were asked to examine the samples and describe the appearance, aroma, flavor, texture, and aftertaste of the cheeses, and then provide a list of attributes individually covering all the aforementioned attributes. Afterward, a roundtable discussion was conducted to reach an agreement on the attributes used and to provide a definition for each attribute. Reference standards were selected for some attributes and were used to anchor the descriptors. Statistical analyses were conducted to assess the performance of the panelists during the training sessions by conducting ANOVA on their training ratings to check for replicate effect and 2-way interactions (panelist $\times$ sample, panelist $\times$ replicate, and sample $\times$ replicate). Ranking tests were performed as well and the performance of the panelists was communicated to them during the training sessions. The final list of 13 attributes with definitions, anchor words, and standards is summarized in Table 1.

The panelists attended 8 evaluation sessions. Two tasting sessions were performed on each test day, one morning and one afternoon session, at least $1 \mathrm{~h}$ after the panelists' last meal at every cheese age period: 0 (i.e., fresh samples), 2, 4, and 8 wk. Panelists were seated in individual booths under white fluorescent lighting. Samples were presented on a tray in $150-\mathrm{mL}$ covered plastic containers labeled with 3-digit random numbers. Water, knife, napkins, standards, and the sensory ballot were provided along with the samples. Panelists assessed 4 different samples at each session and they were instructed to wait for 2 min between samples and to rinse their mouths with water. The cheese samples were cut into $4.5-\times 2-\times 1.5-\mathrm{cm}$ rectangular slices and $1.5-\mathrm{cm}^{3}$ cubes. Each panelist was given 1 slice and 2 cubes of each sample. Preparation of the samples along with the references took place $1 \mathrm{~d}$ before the tasting session and samples were kept stored and covered in the refrigerator $\left(4^{\circ} \mathrm{C}\right)$ until serving. Samples were presented in a counterbalanced order based on the design for 15 samples as suggested by Macfie and Bratchell (1989). The samples were assessed in duplicate evaluations (every period) with all 3 samples (3 salt treatments) served within each replicate. Panelists were asked to rate the intensity of the attributes generated during the training sessions on a 15-cm line scale (Guinard and Cliff, 1987; Guinard et al., 1999). Panelists were compensated for their participation with a small monetary sum.

\section{Hedonic Evaluation}

Seventy-two panelists participated in the acceptability test (mean age $=24.3 \mathrm{yr}$, range $=18-57 \mathrm{yr}$, SD $=8.1$ ). They were mainly students, staff, and faculty members at the American University of Beirut. Panelists were selected based on their willingness to participate and time availability. At the end of the study, a small monetary sum was given to each panelist as compensation for participation.

The panelists assessed all 3 fresh cheese samples in one session in a setting similar to that described above. Panelists were instructed to rinse their mouths with

Table 1. Terms used in descriptive analysis of Halloumi cheese

\begin{tabular}{|c|c|}
\hline Attribute & Definition as worded on score sheet \\
\hline Color & The color of the cheese ranging from chalky white to light ivory \\
\hline Fermented odor & Fermented odor of Light Pitas Halloumi ${ }^{1}$ \\
\hline Milky odor & Odor of heavy cream ${ }^{2}$ \\
\hline Saltiness & Taste elicited by table salt \\
\hline Bitterness & Taste elicited by caffeine \\
\hline Fermented flavor & Flavor of Light Pitas Halloumi ${ }^{1}$ \\
\hline Milky flavor & Flavor of heavy cream ${ }^{2}$ \\
\hline Hardness & The force necessary to cut a cube of Halloumi sample with a metal fork at a $90^{\circ}$ angle \\
\hline Crumbliness & The amount of fracturability of the sample after biting it using the molars and chewing it 3 times \\
\hline Squeakiness & The amplitude of sound upon chewing the sample 3 times \\
\hline Moistness & The amount of water that flows from the sample after chewing it 3 times \\
\hline Bitter aftertaste & Aftertaste elicited by caffeine \\
\hline Salty aftertaste & Taste elicited by table salt \\
\hline
\end{tabular}

${ }^{1}$ Light Pitas Halloumi, Nicosia, Cyprus.

${ }^{2}$ Skim milk (Dairy Day, Bekaa, Lebanon) compared with heavy cream (Elle et Vire, Conde sur Vire, France). 
Table 2. Significance of the effects ( $F$-values) of salt treatment, age of cheese, replicate, and their interactions on the chemical properties of Halloumi samples

\begin{tabular}{|c|c|c|c|c|c|c|}
\hline \multirow[b]{2}{*}{ Chemical analyses } & \multicolumn{3}{|c|}{ Effect } & \multicolumn{3}{|c|}{ Interaction $^{1}$} \\
\hline & $\begin{array}{l}\text { Salt treatment } \\
\quad(\mathrm{df}=2)\end{array}$ & $\begin{array}{l}\text { Age of cheese } \\
(\mathrm{df}=4)\end{array}$ & $\begin{array}{c}\text { Replicate } \\
(\mathrm{df}=2)\end{array}$ & $\begin{array}{c}\mathrm{ST} \times \mathrm{AC} \\
(\mathrm{df}=8)\end{array}$ & $\begin{array}{l}\mathrm{ST} \times \mathrm{R} \\
(\mathrm{df}=4)\end{array}$ & $\begin{array}{l}\mathrm{AC} \times \mathrm{R} \\
(\mathrm{df}=8)\end{array}$ \\
\hline Fat $(\%)$ & 3.53 & $4.49^{*}$ & 1.45 & $3.94^{*}$ & 0.72 & 0.19 \\
\hline Protein (\%) & 3.48 & $68.04^{* * *}$ & 2.50 & 1.50 & 0.41 & 1.92 \\
\hline $\mathrm{pH}$ & $27.92^{* * *}$ & $343.17^{* * *}$ & 1.74 & $10.69^{* * *}$ & 2.94 & 0.73 \\
\hline Potassium (mg/100 g) & $989.81^{* * *}$ & $21.55^{* * *}$ & 0.80 & $11.13^{* * *}$ & 0.21 & 1.31 \\
\hline
\end{tabular}

${ }^{1} \mathrm{ST}=$ salt treatment; $\mathrm{AC}=$ age of cheese; $\mathrm{R}=$ replicate.

${ }^{*} P<0.05 ;{ }^{* *} P<0.01 ;{ }^{* * *} P<0.001$.

water between samples. All samples were prepared 1 $\mathrm{d}$ before serving and were stored in the refrigerator $\left(4^{\circ} \mathrm{C}\right)$ until $15 \mathrm{~min}$ before sensory evaluation. Cheese samples were cut into $1.5-\mathrm{cm}^{3}$ cubes and each panelist was provided with 2 cheese cubes. The samples were presented in 150-mL covered plastic cups labeled with 3-digit random numbers. Samples were provided in a counterbalanced order based on the design for 3 samples as suggested by Macfie and Bratchell (1989). The panelists were asked to taste the samples in the order provided and to rate the samples for appearance, flavor, texture and overall acceptability on a 9-point hedonic scale $(1=$ dislike extremely to $9=$ like extremely; Peryam and Pilgrim 1957).

\section{Statistical Analyses}

Analysis of variance using the GLM procedure of SAS (version 8.02, SAS Institute Inc., Cary, NC) was conducted to assess the performance of panelists (ability to discriminate among samples, reproducibility, and concept alignment) during panel training and to assess the significance of chemical, physical, and sensory differences among the experimental samples in the evalua- tion sessions. In the statistical model for the descriptive sensory data, the response variable was the sensory attribute of the samples. Factors in the model were salt treatment (3 treatments), age of cheese $(0,2,4$, and 8 wk), panelist, replicate, and their 2-way interactions. Panelist was included as a random effect and the other variables were fixed effects in the model. Each of the main effects was tested as well as their interactions. Panelist was not included in the chemical, physical, and microbiological analyses models. In addition, the sensory acceptability model included only salt treatment and panelist. Significant means for the sensory analyses were separated by Tukey's honestly significant difference (HSD) test. Significance was established at $\alpha<0.05$.

\section{RESULTS AND DISCUSSION}

\section{Physicochemical Analyses}

Results of the chemical analyses are presented in Tables 2, 3, and 4. Analyses of variance showed that salt treatment had a significant effect $(P<0.001)$ on the $\mathrm{pH}$, sodium, and potassium contents of the cheese

Table 3. Least squares means of the chemical properties of Halloumi samples for the different salt treatments and cheese ages

\begin{tabular}{|c|c|c|c|c|c|c|c|c|}
\hline \multirow[b]{2}{*}{ Chemical analysis } & \multicolumn{3}{|c|}{ Salt treatment ${ }^{1}$} & \multicolumn{5}{|c|}{ Age of cheese (wk) } \\
\hline & $\mathrm{A}$ & B & $\mathrm{C}$ & 0 & 2 & 4 & 6 & 8 \\
\hline Protein $^{2}(\%)$ & 17.67 & 17.05 & 16.87 & $19.22^{\mathrm{a}}$ & - & $16.84^{\mathrm{b}}$ & - & $15.54^{\mathrm{c}}$ \\
\hline $\mathrm{pH}$ & $6.30^{\mathrm{b}}$ & $6.33^{\mathrm{b}}$ & $6.42^{\mathrm{a}}$ & $6.52^{\mathrm{a}}$ & $6.56^{\mathrm{a}}$ & $6.54^{\mathrm{a}}$ & $6.18^{\mathrm{b}}$ & $5.93^{\mathrm{c}}$ \\
\hline Lactic acid (\%) & 0.27 & 0.29 & 0.25 & $0.20^{\mathrm{c}}$ & $0.18^{\mathrm{cd}}$ & $0.15^{\mathrm{d}}$ & $0.30^{\mathrm{b}}$ & $0.53^{\mathrm{a}}$ \\
\hline
\end{tabular}

${ }^{\mathrm{a}-\mathrm{d}}$ Means within a salt treatment or age of cheese and within a row with different superscripts are significantly different $(P<0.05)$.

${ }^{1}$ Salt treatments: $\mathrm{A}=100 \% \mathrm{NaCl}$ (control); $\mathrm{B}=70 \% \mathrm{NaCl}, 30 \% \mathrm{KCl} ; \mathrm{C}=50 \% \mathrm{NaCl}, 50 \% \mathrm{KCl}$.

${ }^{2}$ For fat and protein analyses, wk 4 actually corresponds to wk 5 . 


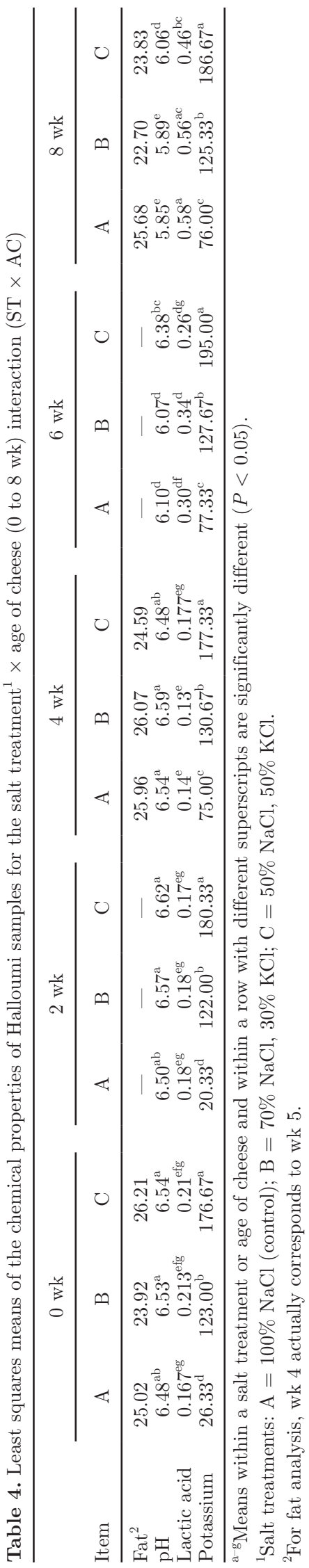

samples, whereas age of the cheese had a significant effect $(P<0.001)$ on the $\mathrm{pH}$, protein, lactic acid, potassium, and sodium contents of the samples, in addition to fat content $(P<0.05)$. No significant differences of salt treatment on moisture, fat, or protein contents were found, in a similar trend to previous studies (Ayyash and Shah, 2010, 2011b), whereas age of the cheese samples did not affect moisture content, unlike in previous studies (Ayyash and Shah, 2010), probably because of the difference in brine concentration $(18 \%$ in the latter study vs. $10 \%$ in our work). We did, however, find significant salt treatment $\times$ age of cheese interactions for fat content $(P<0.05)$, $\mathrm{pH}$ and potassium content $(P<0.001)$, and lactic acid levels $(P<0.01)$. No replicate, salt treatment $x$ replicate, or age of cheese $\times$ replicate effects were found.

Samples stored in $\mathrm{NaCl} / \mathrm{KCl}$ brines had lower sodium levels than those stored in pure $\mathrm{NaCl}$ brine, with significantly decreasing values between the A, B, and C treatments, respectively (Table 3). The opposite trend was true for the potassium content of the different salt treatment solutions, as would be expected from the design of the study. Moreover, cheese maturation caused a significant decrease in sodium content, with samples matured for 4,6 , and 8 wk having significantly lower sodium levels than fresh and 2-wk Halloumi samples. On the other hand, the potassium content of the cheeses significantly increased after 2 wk of maturation. Moreover, a significant decrease in protein content was obtained between the cheeses at wk 0,4 , and 8 and was an indication of increased proteolysis during maturation as described in previous studies that examined the effects of partial substitution of $\mathrm{KCl}$ with $\mathrm{NaCl}$ in brine solution on Feta-type and Halloumi cheeses (Aly, 1995; Ayyash and Shah, 2010). pH was significantly lower for salt treatments $\mathrm{A}(100 \% \mathrm{NaCl})$ and $\mathrm{B}(70 \% \mathrm{NaCl}$, $30 \% \mathrm{KCl})$ than for treatment $\mathrm{C}(50 \% \mathrm{NaCl}, 50 \% \mathrm{KCl})$. This is consistent with the findings of Ayyash and Shah (2010) and Ayyash and Shah (2011b), who attributed this trend to the higher $\mathrm{pH}$ of $\mathrm{KCl}$ compared with $\mathrm{NaCl}$. Karagözlü et al. (2008) reported an inverse trend for white pickled cheese, noting that the acidity of cheeses was found to increase significantly with decreasing $\mathrm{NaCl}$ added. Moreover, results showed a decrease in $\mathrm{pH}$ in mature 6- and 8-wk samples, which was associated with the significant increase in lactic acid content of these 2 cheeses, probably caused by the fermentation of lactose by nonstarter lactic acid bacteria (Papademas, 2006). These results are in accordance with previous studies (Papademas and Robinson, 2000; Milci et al., 2005). The absence of significant differences in moisture content between fresh and mature Halloumi cheeses has been previously reported (Papademas and Robinson, $2000)$. For the salt treatment $\times$ age of cheese interac- 
Table 5. Significance of the effects ( $F$-values) of salt treatment, age of cheese, replicate, and their interactions on the physical properties of Halloumi samples ${ }^{1}$

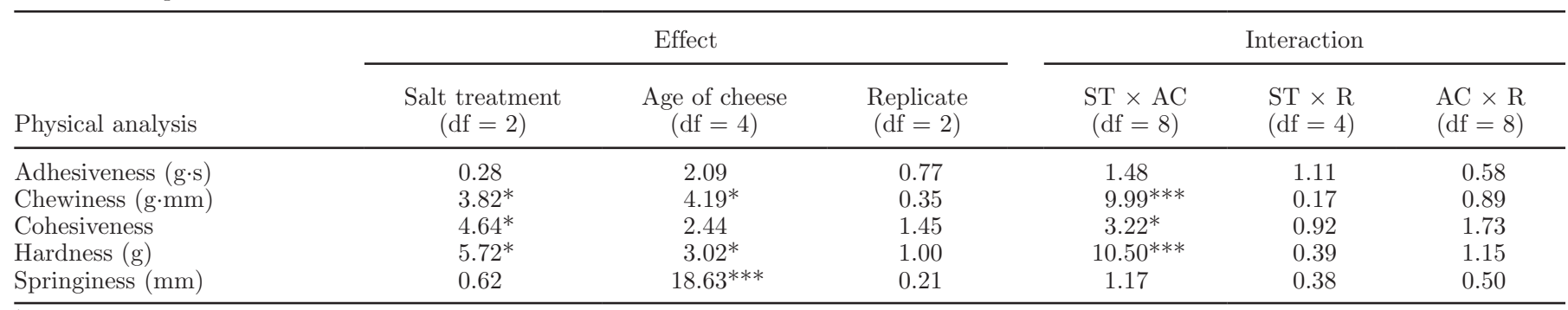

${ }^{1} \mathrm{ST}=$ salt treatment; $\mathrm{AC}=$ age of cheese; $\mathrm{R}=$ replicate.

$* P<0.05 ; * * * P<0.001$.

tion, $\mathrm{pH}$ did not differ significantly within treatment or between treatments until wk 6 of maturation. At wk 6 and 8 , the $\mathrm{pH}$ of treatments $\mathrm{A}$ and $\mathrm{B}$ was significantly lower than that of treatment $\mathrm{C}$. This was accompanied by a significant increase in lactic acid content at wk 6 and 8 , whereby samples treated with salt solutions A and $\mathrm{B}$ had the highest lactic acid content at wk 8. Potassium content did not significantly differ within same treatment for all fresh and matured cheeses, except for wk 6 and 8 for the A treatment, which was significantly higher than in the previous weeks. This is a surprising outcome because one could expect an increase in potassium in treatments B and C as obtained by Ayyash and Shah (2010) but not for the control treatment (A). Fat content did not differ significantly between the different salt treatment by age of cheese combinations. The lack of increase in potassium with storage in treatments $\mathrm{B}$ and $\mathrm{C}$ is consistent with a previous study with Mozzarella that included lower brine concentrations (4\% in Ayyash and Shah, 2011c) but not with Halloumi studies with higher brine concentrations (18\% in Ayyash and Shah, 2010).

The results of the texture analyses are summarized in Tables 5, 6, and 7. Salt treatment had a significant effect on chewiness, cohesiveness, and hardness $(P<$ $0.05)$, whereas age of cheese had a significant effect on springiness $(P<0.001)$, chewiness, and hardness $(P$ $<0.05)$. A significant salt treatment $\times$ age of cheese interaction was obtained for chewiness, hardness $(P<$ $0.001)$, and cohesiveness $(P<0.05)$. No significant effects were obtained for replicate, salt treatment $\times$ replicate, and age of cheese $\times$ replicate. Brine A samples were more chewy than B samples but not significantly different from the $\mathrm{C}$ samples. The same trend was true for hardness. On the other hand, B samples were more cohesive than A or C samples. Halloumi samples matured for 6 and 8 wk were significantly less springy than fresh samples and those matured for 2 and $4 \mathrm{wk}$ (Table 6). Similar findings were reported by Papademas and Robinson (2000), who found that the structure of Halloumi cheese changed dramatically at maturity. In particular, the mature cheese was much less springy than the fresh sample, as determined by a sensory panel. In addition, 2-wk-old samples were more chewy than the fresh or 4-wk samples but not significantly different from the other samples. As shown from the values in Table 7 , in general, no significant differences were found between treatments in the same period with the exception of chewiness and hardness in wk 6 and 8 , where the values were not consistent with trends observed in the previous or subsequent period. Ayyash et al. (2011) noted an absence of differences on texture profile analysis parameters for the same age. However, the latter study revealed a significant decrease in hardness and cohesiveness with storage, which was not the case in this work.

Table 6. Least squares means of the physical properties of Halloumi samples for the different salt treatments and cheese ages

\begin{tabular}{|c|c|c|c|c|c|c|c|c|}
\hline Physical analysis & \multicolumn{3}{|c|}{ Salt treatment ${ }^{1}$} & \multicolumn{5}{|c|}{ Age of cheese (wk) } \\
\hline Adhesiveness $(\mathrm{g} \cdot \mathrm{s}$ ) & -4.32 & -3.73 & -3.41 & -3.22 & -4.71 & -3.42 & -6.05 & -1.68 \\
\hline Cohesiveness & $0.80^{\mathrm{b}}$ & $0.82^{\mathrm{a}}$ & $0.80^{\mathrm{b}}$ & 0.81 & 0.81 & 0.81 & 0.80 & 0.78 \\
\hline Hardness (g) & $950.03^{\mathrm{a}}$ & $715.25^{\mathrm{b}}$ & $898.97^{\mathrm{ab}}$ & 729.69 & 989.13 & 739.62 & 883.44 & 931.87 \\
\hline Springiness (mm) & 2.34 & 2.38 & 2.37 & $2.44^{\mathrm{a}}$ & $2.51^{\mathrm{a}}$ & $2.43^{\mathrm{a}}$ & $2.25^{\mathrm{b}}$ & $2.17^{\mathrm{b}}$ \\
\hline
\end{tabular}

${ }^{\mathrm{a}, \mathrm{b}}$ Means within a salt treatment or age of cheese and within a row with different superscripts are significantly different $(P<0.05)$.

${ }^{1}$ Salt treatments: $\mathrm{A}=100 \% \mathrm{NaCl}$ (control); $\mathrm{B}=70 \% \mathrm{NaCl}, 30 \% \mathrm{KCl} ; \mathrm{C}=50 \% \mathrm{NaCl}, 50 \% \mathrm{KCl}$. 


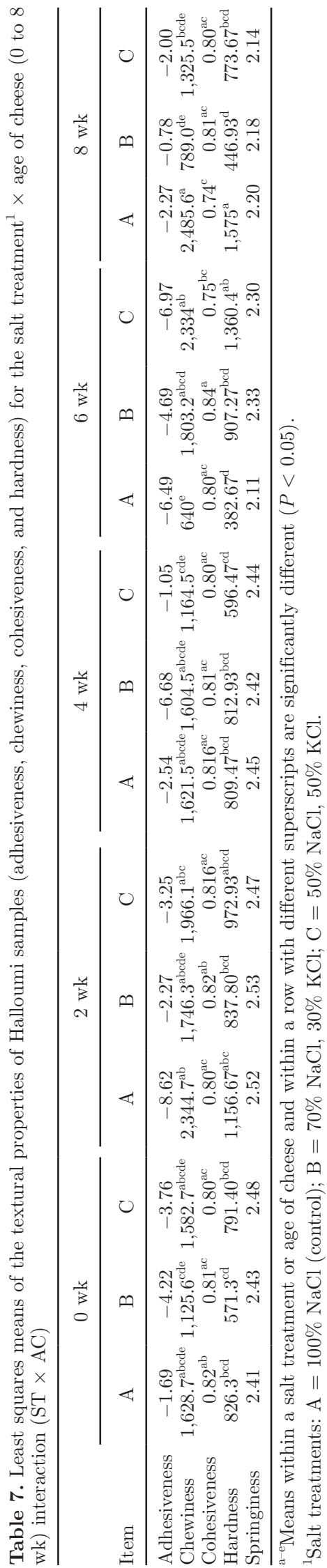

\section{Microbiological Results}

The effect of substitution of $\mathrm{NaCl}$ by $\mathrm{KCl}$ on ANOVA and the least squares means for total bacterial counts, lactic acid bacteria (LAB), psychrophilic bacteria, total coliforms, and yeasts and molds attributes for each of the 3 salt treatments (A, B, and C) and for the 5 ages of cheese $(0,2,4,6$, and $8 \mathrm{wk})$ are summarized in Tables 8, 9, and 10, respectively. A significant salt treatment effect was found for psychrophilic bacteria, TBC, and total coliforms $(P<0.001)$. In addition, all observed microorganisms increased significantly $(P<$ 0.001) during storage in the control sample (A) and in the other 2 experimental samples (B and $\mathrm{C}$ ). This pattern of variation has been observed in different white brined cheeses (Litopoulou-Tzanetaki and Tzanekatis, 1992; Manolopoulou et al., 2003; Öner et al., 2006). More importantly, a significant salt treatment $\times$ age of cheese interaction was obtained for all microorganisms. The TBC differed significantly $(P<0.05)$ among different brine solutions after 2,6 , and $8 \mathrm{wk}$ of storage (Table 10). They were slightly lower in the control than in the experimental cheeses. The TBC in cheeses brined in the 3 different solutions are lower than those mentioned by Milci et al. (2005) in Halloumi cheese, by Öner et al. (2006) in Turkish artisanal white brined cheese, and by Kursun et al. (2011) in white pickled cheese. This difference could be related to hygiene practices and to the fact that Halloumi cheese is boiled in whey before brining. Psychrophilic bacteria varied significantly $(P<0.05)$ among different brine solutions at the same age. In general, psychrophilic counts were, to some extent, higher in the experimental cheeses than in the control cheese, except in wk 8 where their count was higher in control samples. Psychrophilic counts in our experiment were lower than those mentioned by Öner et al. (2006) in Turkish artisanal white cheese. The LAB are a group of microorganisms that may affect the ripening process and the sensory characteristics of cheeses due to the production of different organic acids and different aroma compounds (Olson, 1990; Leroy and De Vuyst, 2004; Öner et al., 2006). Nonstarter LAB in Halloumi cheese stored in different brines solutions increased significantly $(P<0.05)$ independently of the brine solution composition in a similar manner to that obtained by Ayyash and Shah (2010). They did not differ between the control sample and the other treatments (B and $\mathrm{C}$ ) at the same periods of storage. As such, the substitution of $\mathrm{NaCl}$ by $\mathrm{KCl}$ did not have a significant effect on the growth of nonstarter LAB. These findings were in agreement with the results of Anjan Reddy and Marth (1995) and Ayyash and Shah (2010), where the substitution of $\mathrm{NaCl}$ by $\mathrm{KCl}$ did not affect the growth of LAB in Cheddar and Halloumi 
Table 8. Significance of the effects ( $F$-values) of salt treatment, age of cheese, replicate, and their interactions on the microbiological properties of Halloumi samples

\begin{tabular}{|c|c|c|c|c|c|c|}
\hline \multirow[b]{2}{*}{ Microorganism $^{2}$} & \multicolumn{3}{|c|}{ Effect } & \multicolumn{3}{|c|}{ Interaction $^{1}$} \\
\hline & $\begin{array}{l}\text { Salt treatment } \\
\quad(\mathrm{df}=2)\end{array}$ & $\begin{array}{l}\text { Age of cheese } \\
\quad(\mathrm{df}=4)\end{array}$ & $\begin{array}{l}\text { Replicate } \\
(\mathrm{df}=1)\end{array}$ & $\begin{array}{c}\mathrm{ST} \times \mathrm{AC} \\
(\mathrm{df}=8)\end{array}$ & $\begin{array}{l}\mathrm{ST} \times \mathrm{R} \\
(\mathrm{df}=2)\end{array}$ & $\begin{array}{l}\mathrm{AC} \times \mathrm{R} \\
(\mathrm{df}=4)\end{array}$ \\
\hline TBC & $57.78^{* * *}$ & $1,091.34^{* * *}$ & 0.35 & $23.71^{* * *}$ & 0.12 & 0.14 \\
\hline LAB & 0.64 & $594.92^{* * *}$ & 2.11 & $4.99^{*}$ & 0.91 & 1.32 \\
\hline $\mathrm{TC}$ & $247.06^{* * *}$ & $4,269.03^{* * *}$ & $10.08^{*}$ & $31.78^{* * *}$ & 0.71 & 0.90 \\
\hline
\end{tabular}

${ }^{1} \mathrm{ST}=$ salt treatment; $\mathrm{AC}=$ age of cheese; $\mathrm{R}=$ replicate.

${ }^{2}$ Psychro $=$ psychrophilic bacteria; $\mathrm{TBC}=$ total bacteria; $\mathrm{LAB}=$ lactic acid bacteria; $\mathrm{TC}=$ total coliforms; $\mathrm{YM}=$ yeasts and molds.

$* P<0.05 ; * * * P<0.001$

cheeses, respectively. Total coliforms reached 4.89, 4.78, and $5.46 \log _{10} \mathrm{cfu} / \mathrm{g}$, respectively, in treatments A, B, and $\mathrm{C}$ after 8 wk of storage in brines. Total coliforms counts were, for most ages, slightly higher, although not always significantly, in cheeses stored in brine solution $\mathrm{C}(50 \% \mathrm{NaCl}, 50 \% \mathrm{KCl})$. However, total coliforms counts in Halloumi cheese samples brined in low concentration solutions $(10 \%$ salts) were lower than those mentioned by Öner et al. (2006) in white brined traditional cheese and within the range of Turantaş et al. (1989) in Turkish white cheeses. Yeasts and molds are responsible for spoilage and fermentation activity, and they affect the quality and acceptability of the product (Fleet, 1990). Yeasts and molds counts did not show any significant difference among cheeses brined in different solutions at the same period of storage. Accordingly, the substitution of $\mathrm{NaCl}$ by $\mathrm{KCl}$ did not affect their growth during storage. In addition, their counts were within the range found by Turantaş et al. (1989) in Turkish white cheeses and higher than the results of Irkin (2010) in Dil cheese.

\section{Descriptive Analysis}

The results of the analyses of variance for the sensory data and the least squares means of all 13 sensory at- tributes for each of the 3 salt treatments (A, B, and C) and for the 4 ages of cheese $(0,2,4$, and $8 \mathrm{wk})$ are summarized in Tables 11, 12, and 13, respectively. Analyses of variance revealed a significant difference between salt treatments for bitterness, fermented flavor $(P<$ $0.01)$, crumbliness, and moistness $(P<0.05)$. Age of cheese was significant for saltiness and squeakiness $(P$ $<0.05$ ). Cheeses salted with treatments $\mathrm{B}$ and $\mathrm{C}$ were significantly more bitter $(P<0.05)$ than those salted with treatment $\mathrm{A}$, as expected. Crumbliness was rated highest for treatment $\mathrm{A}$ and differed significantly ( $P$ $<0.05$ ) from that of treatment C. Previous studies on Feta (Katsiari et al., 1997) and Kefalograviera cheeses (Katsiari et al., 1997, 1998) revealed that cheeses salted with $\mathrm{NaCl} / \mathrm{KCl}$ mixtures were slightly more fracturable compared with those salted exclusively with $\mathrm{NaCl}$, even though no significant difference was found in textural properties. Moistness was rated lowest for treatment A and differed significantly $(P<0.05)$ from that of treatment B. Cheeses matured for 2 wk were significantly less salty $(P<0.05)$ than fresh, 4 -, and 8 -wk-old cheeses. Previous studies had determined that, at maturity, flavor notes such as salty increased significantly in intensity (Papademas and Robinson, 2000, 2001; Kaminarides et al., 2007). However, this increased saltiness did not carry over to the subsequent weeks.

Table 9. Least squares means of the microbial counts of Halloumi samples for the different salt treatments and cheese ages

\begin{tabular}{|c|c|c|c|c|c|c|c|c|}
\hline Microorganism $^{1}$ & \multicolumn{3}{|c|}{ Salt treatment ${ }^{2}$} & \multicolumn{5}{|c|}{ Age of cheese (wk) } \\
\hline Psychro & $5.62^{\mathrm{c}}$ & $5.68^{\mathrm{b}}$ & $5.81^{\mathrm{a}}$ & $3.92^{\mathrm{e}}$ & $5.36^{\mathrm{d}}$ & $6.01^{\mathrm{c}}$ & $6.42^{\mathrm{b}}$ & $6.81^{\mathrm{a}}$ \\
\hline LAB & 4.43 & 4.39 & 4.45 & $3.04^{\mathrm{e}}$ & $3.86^{\mathrm{d}}$ & $4.20^{\mathrm{c}}$ & $4.81^{\mathrm{b}}$ & $6.22^{\mathrm{a}}$ \\
\hline $\mathrm{TC}$ & $3.34^{\mathrm{b}}$ & $3.22^{\mathrm{c}}$ & $3.61^{\mathrm{a}}$ & $2.33^{\mathrm{e}}$ & $2.72^{\mathrm{d}}$ & $3.14^{\mathrm{c}}$ & $3.72^{\mathrm{b}}$ & $5.04^{\mathrm{a}}$ \\
\hline YM & 5.08 & 5.16 & 5.16 & $3.84^{\mathrm{d}}$ & $4.48^{\mathrm{c}}$ & $5.20^{\mathrm{b}}$ & $5.95^{\mathrm{a}}$ & $6.20^{\mathrm{a}}$ \\
\hline
\end{tabular}

${ }^{\mathrm{a} e}$ Means within a salt treatment or age of cheese and within a row with different superscripts are significantly different $(P<0.05)$.

${ }^{1}$ Psychro $=$ psychrophilic bacteria $; \mathrm{TBC}=$ total bacteria $; \mathrm{LAB}=$ lactic acid bacteria; $\mathrm{TC}=$ total coliforms; $\mathrm{YM}=$ yeasts and molds.

${ }^{2}$ Salt treatments: $\mathrm{A}=100 \% \mathrm{NaCl}$ (control); $\mathrm{B}=70 \% \mathrm{NaCl}, 30 \% \mathrm{KCl} ; \mathrm{C}=50 \% \mathrm{NaCl}, 50 \% \mathrm{KCl}$. 
Table 10. Least squares means of the microbial counts of Halloumi samples for the salt treatment ${ }^{1} \times$ age of cheese $(0$ to 8 wk) interaction $(\mathrm{ST}$ $\times \mathrm{AC})$

\begin{tabular}{|c|c|c|c|c|c|c|c|c|c|c|c|c|c|c|c|}
\hline \multirow[b]{2}{*}{ Microorganism $^{2}$} & \multicolumn{3}{|c|}{$0 \mathrm{wk}$} & \multicolumn{3}{|c|}{$2 \mathrm{wk}$} & \multicolumn{3}{|c|}{$4 \mathrm{wk}$} & \multicolumn{3}{|c|}{$6 \mathrm{wk}$} & \multicolumn{3}{|c|}{$8 \mathrm{wk}$} \\
\hline & A & B & $\mathrm{C}$ & $\mathrm{A}$ & $\mathrm{B}$ & $\mathrm{C}$ & $\mathrm{A}$ & $\mathrm{B}$ & $\mathrm{C}$ & $\mathrm{A}$ & B & $\mathrm{C}$ & $\mathrm{A}$ & $\mathrm{B}$ & $\mathrm{C}$ \\
\hline Psychro & $3.41^{1}$ & $4.24^{\mathrm{j}}$ & $4.10^{\mathrm{k}}$ & $5.38^{\mathrm{h}}$ & $5.25^{\mathrm{i}}$ & $5.46^{\mathrm{g}}$ & $5.80^{\mathrm{f}}$ & $5.93^{\mathrm{e}}$ & $6.30^{\mathrm{d}}$ & $6.37^{\mathrm{d}}$ & $6.38^{\mathrm{d}}$ & $6.51^{\mathrm{c}}$ & $7.13^{\mathrm{a}}$ & $6.63^{\mathrm{b}}$ & $6.68^{\mathrm{b}}$ \\
\hline $\mathrm{TBC}$ & $3.19^{\mathrm{i}}$ & $3.17^{\mathrm{i}}$ & $3.085^{\mathrm{i}}$ & $3.41^{\text {gh }}$ & $4.02^{\mathrm{ef}}$ & $3.74^{\mathrm{fg}}$ & $3.95^{\mathrm{ef}}$ & $4.31^{\mathrm{de}}$ & $4.11^{\mathrm{ef}}$ & $4.03^{\text {ef }}$ & $5.01^{\mathrm{c}}$ & $4.57^{\mathrm{d}}$ & $5.87^{\mathrm{b}}$ & $5.75^{\mathrm{b}}$ & $6.39^{\mathrm{a}}$ \\
\hline LAB & $2.91^{\mathrm{f}}$ & $3.24^{\mathrm{ef}}$ & $2.98^{\mathrm{f}}$ & $4.00^{\mathrm{d}}$ & $3.83^{\mathrm{d}}$ & $3.77^{\text {de }}$ & $4.21^{\mathrm{cd}}$ & $4.24^{\mathrm{cd}}$ & $4.16^{\mathrm{d}}$ & $4.72^{\mathrm{bc}}$ & $4.80^{\mathrm{b}}$ & $4.91^{\mathrm{b}}$ & $6.31^{\mathrm{a}}$ & $5.88^{\mathrm{a}}$ & $6.46^{\mathrm{a}}$ \\
\hline $\mathrm{TC}$ & $2.32^{\mathrm{i}}$ & $2.08^{\mathrm{j}}$ & $2.59^{\mathrm{h}}$ & $2.59^{\mathrm{h}}$ & $2.74^{\mathrm{gh}}$ & $2.83^{\mathrm{g}}$ & $3.11^{\mathrm{f}}$ & $3.11^{\mathrm{f}}$ & $3.20^{\mathrm{f}}$ & $3.78^{\mathrm{d}}$ & $3.42^{\mathrm{e}}$ & $3.97^{\mathrm{c}}$ & $4.89^{\mathrm{b}}$ & $4.78^{\mathrm{b}}$ & $5.46^{\mathrm{a}}$ \\
\hline YM & $3.94^{\mathrm{ef}}$ & $4.04^{\mathrm{ef}}$ & $3.54^{\mathrm{f}}$ & $4.47^{\mathrm{de}}$ & $4.46^{\mathrm{de}}$ & $4.52^{\text {de }}$ & $5.13^{\text {bcd }}$ & $5.12^{\mathrm{cd}}$ & $5.36^{\text {bcd }}$ & $5.7^{\mathrm{abc}}$ & $6.36^{\mathrm{a}}$ & $5.80^{\mathrm{abc}}$ & $6.15^{\mathrm{a}}$ & $5.84^{\mathrm{abc}}$ & $6.60^{\mathrm{a}}$ \\
\hline
\end{tabular}

${ }^{\mathrm{a}-\mathrm{l}}$ Means within a salt treatment or age of cheese and within a row with different superscripts are significantly different $(P<0.05)$.

${ }^{1}$ Salt treatments: $\mathrm{A}=100 \% \mathrm{NaCl}$ (control); $\mathrm{B}=70 \% \mathrm{NaCl}, 30 \% \mathrm{KCl} ; \mathrm{C}=50 \% \mathrm{NaCl}, 50 \% \mathrm{KCl}$.

${ }^{2}$ Psychro $=$ psychrophilic bacteria; $\mathrm{TBC}=$ total bacteria; $\mathrm{LAB}=$ lactic acid bacteria; $\mathrm{TC}=$ total coliforms; YM $=$ yeasts and molds.

Squeakiness, on the other hand, was rated highest in fresh and 2-wk-old cheeses and was significantly different $(P<0.05)$ than the ratings for cheeses that were matured for 4 and 8 wk. Squeakiness is characteristic of fresh Halloumi cheese and is lost over time as the cheese matures. This could be due to the loss of firmness of the cheese, which has been attributed to a loss of calcium and the effect of proteolysis, in addition to the relative loss of microstructure voids that occurs as the cheese matures (Ayyash et al., 2011).

A significant salt treatment $\times$ age of cheese interaction was observed for fermented flavor $(P<0.001)$ and milky flavor $(P<0.01)$. The least squares means for these 2 descriptive attributes for the different salt treatments and cheese ages are shown in Table 13. With regard to the age of the cheeses, treatments did not differ significantly at the same age, except for wk 4 where treatment B scored highest on fermented flavor, followed by treatment $\mathrm{A}$ and then $\mathrm{C}$, although the latter 2 treatments did not differ significantly between each other. Within the same salt treatment, fresh samples of treatment B had a significantly less intense fermented flavor than samples matured for 2, 4, and $8 \mathrm{wk}$. It would be interesting to assess if the levels of fermented flavor are related to the extent of proteolysis in the cheese. Ayyash and Shah (2011a) reported that Halloumi cheeses kept in various ratios of $\mathrm{NaCl}$ and $\mathrm{KCl}$ brine solutions showed similar proteolytic patterns to cheeses kept in $18 \% \mathrm{NaCl}$ brine solution (control). No significant differences were found in milky flavor between salt treatments at the same age. Milk flavor in treatment B had a significantly higher score for fresh samples than it did for samples matured for $4 \mathrm{wk}$.

Analyses of variance revealed significant differences for panelist for all attributes except hardness, which is always an expected outcome given the general difference between the panelists in terms of their usage of the $15-\mathrm{cm}$ line scale. No major inconsistencies were found in the panelists' ratings, as shown by the absence of replicate effect except for color $(P<0.01)$. A

Table 11. Significance of the effects ( $F$-values) of panelist, salt treatment, age of cheese, replicate, and their interactions on the sensory properties of Halloumi samples

\begin{tabular}{|c|c|c|c|c|c|c|c|c|c|c|}
\hline \multirow[b]{2}{*}{ Attribute } & \multicolumn{4}{|c|}{ Effect } & \multicolumn{6}{|c|}{ Interaction $^{1}$} \\
\hline & $\begin{array}{l}\text { Panelist } \\
(\mathrm{df}=8)\end{array}$ & $\begin{array}{c}\text { Salt } \\
\text { treatment } \\
(\mathrm{df}=2)\end{array}$ & $\begin{array}{l}\text { Age of cheese } \\
\quad(\mathrm{df}=3)\end{array}$ & $\begin{array}{c}\text { Replicate } \\
(\mathrm{df}=1)\end{array}$ & $\begin{array}{c}\mathrm{ST} \times \mathrm{AC} \\
(\mathrm{df}=6)\end{array}$ & $\begin{array}{l}\mathrm{ST} \times \mathrm{R} \\
(\mathrm{df}=2)\end{array}$ & $\begin{array}{l}\mathrm{AC} \times \mathrm{R} \\
(\mathrm{df}=3)\end{array}$ & $\begin{array}{l}\mathrm{ST} \times \mathrm{P} \\
(\mathrm{df}=16)\end{array}$ & $\begin{array}{c}\mathrm{AC} \times \mathrm{P} \\
(\mathrm{df}=24)\end{array}$ & $\begin{array}{c}\mathrm{R} \times \mathrm{P} \\
(\mathrm{df}=8)\end{array}$ \\
\hline Color & $12.09 * * *$ & 1.19 & 0.26 & $13.80^{* *}$ & 2.13 & 1.21 & 1.81 & 1.19 & $2.59^{* * *}$ & 0.66 \\
\hline Fermented odor & $6.50^{* * *}$ & 1.22 & 1.53 & 0.13 & 1.95 & 1.71 & 0.49 & $2.02^{*}$ & $3.12^{* * *}$ & 1.15 \\
\hline Milky odor & $6.59^{* *}$ & 0.21 & 1.10 & 0.37 & 0.90 & 0.68 & 0.74 & $1.96^{*}$ & 1.52 & 0.76 \\
\hline Fermented flavor & $5.19^{* * *}$ & $8.50^{* *}$ & 2.38 & 1.10 & $4.89^{* * *}$ & $3.07^{*}$ & 1.06 & 1.25 & $7.22^{* * *}$ & 0.93 \\
\hline Milky flavor & $6.22 * * *$ & 0.75 & 0.94 & 0.01 & $3.56^{* *}$ & 0.77 & 0.30 & 0.76 & $4.25^{* * *}$ & 1.66 \\
\hline Hardness & 0.75 & 2.60 & 2.89 & 0.10 & 0.90 & $6.72^{* *}$ & 1.36 & 0.54 & $6.43^{* * *}$ & 1.57 \\
\hline Crumbliness & $4.00^{* *}$ & $3.74^{*}$ & 1.28 & 0.08 & 0.34 & 0.67 & $2.84^{*}$ & 1.17 & $5.37^{* * *}$ & 0.90 \\
\hline Squeakiness & $18.39 * * *$ & 0.08 & $4.38^{*}$ & 3.10 & 1.06 & 2.71 & 1.43 & 0.54 & $2.74 * * *$ & 0.53 \\
\hline Moistness & $5.94^{* *}$ & $3.93^{*}$ & 1.26 & 1.33 & 0.26 & 0.13 & 1.04 & 1.26 & $3.17^{* * *}$ & 0.92 \\
\hline Bitter aftertaste & $10.20^{* * *}$ & 3.33 & 1.84 & 0.22 & 0.84 & 0.63 & 0.76 & 1.07 & $1.85^{*}$ & 1.09 \\
\hline
\end{tabular}

${ }^{1} \mathrm{ST}=$ salt treatment; $\mathrm{AC}=$ age of cheese; $\mathrm{R}=$ replicate; $\mathrm{P}=$ panelist.

${ }^{*} P<0.05 ;{ }^{* *} P<0.01 ;{ }^{* * *} P<0.001$. 
Table 12. Least squares means of descriptive analysis attributes of Halloumi samples (rated on a 15-cm line scale) for the different salt treatments and ages

\begin{tabular}{|c|c|c|c|c|c|c|c|}
\hline \multirow[b]{2}{*}{ Attribute } & \multicolumn{3}{|c|}{ Salt treatment ${ }^{1}$} & \multicolumn{4}{|c|}{ Age of cheese (wk) } \\
\hline & $\mathrm{A}$ & B & $\mathrm{C}$ & 0 & 2 & 4 & 8 \\
\hline Color & 10.74 & 10.25 & 10.26 & 10.41 & 10.61 & 10.54 & 10.10 \\
\hline Fermented odor & 6.93 & 7.46 & 6.64 & 6.19 & 7.15 & 6.90 & 7.80 \\
\hline Milky odor & 6.73 & 6.54 & 6.33 & 7.20 & 6.38 & 6.34 & 6.20 \\
\hline Saltiness & 6.92 & 6.80 & 6.74 & $7.34^{\mathrm{a}}$ & $5.67^{\mathrm{b}}$ & $6.75^{\mathrm{a}}$ & $7.52^{\mathrm{a}}$ \\
\hline Bitterness & $3.08^{\mathrm{b}}$ & $4.29^{\mathrm{a}}$ & $3.92^{\mathrm{a}}$ & 4.01 & 3.69 & 3.50 & 3.86 \\
\hline Fermented flavor & $6.33^{\mathrm{b}}$ & $7.17^{\mathrm{a}}$ & $5.97^{\mathrm{b}}$ & 5.35 & 6.32 & 6.81 & 7.50 \\
\hline Milky flavor & 5.87 & 6.11 & 6.18 & 6.53 & 5.74 & 5.52 & 6.43 \\
\hline Hardness & 6.94 & 6.42 & 6.59 & 7.46 & 6.40 & 5.19 & 7.54 \\
\hline Crumbliness & $8.20^{\mathrm{a}}$ & $7.81^{\mathrm{ab}}$ & $7.38^{\mathrm{b}}$ & 8.38 & 7.47 & 7.13 & 8.21 \\
\hline Squeakiness & 8.23 & 8.26 & 8.33 & $8.64^{\mathrm{a}}$ & $9.43^{\mathrm{a}}$ & $7.50^{\mathrm{b}}$ & $7.52^{\mathrm{b}}$ \\
\hline Moistness & $6.86^{\mathrm{b}}$ & $7.88^{\mathrm{a}}$ & $7.21^{\mathrm{ab}}$ & 8.08 & 6.89 & 7.04 & 7.26 \\
\hline Bitter aftertaste & 2.99 & 3.72 & 3.68 & 3.40 & 3.37 & 2.98 & 4.10 \\
\hline Salty aftertaste & 6.03 & 5.85 & 5.73 & 5.78 & 5.14 & 5.67 & 6.90 \\
\hline
\end{tabular}

significant salt treatment $\times$ replicate interaction was found for fermented flavor $(P<0.05)$ and hardness $(P$ $<0.01)$, whereas a significant age of cheese $\times$ replicate interaction was found for crumbliness $(P<0.05)$. Salt treatment $\times$ panelist was significant for fermented odor and milky odor $(P<0.05)$. A significant age of cheese $\times$ panelist interaction was found for all attributes except milky odor and bitterness. No replicate $\times$ panelist interaction was observed.

\section{Hedonic Evaluation}

Analyses of variance and the least squares means of the acceptability scores of Halloumi samples for the 3 salt treatments are displayed in Table 14. The ANOVA revealed significant differences for panelist $(P<0.001)$ for all acceptability scores, whereas salt treatment had no significant effect on any of the acceptability variables despite the fact that the absolute scores tended to slightly decrease with an increase in sodium substitution. These findings are in accordance with a study conducted by Al-Otaibi and Wilbey (2006), who found that using a different $\mathrm{Na}: \mathrm{K}$ ratio in experimental salt treatments did not significantly affect the acceptabil- ity of white salted cheese. Similar findings have been reported in studies on Kefalograviera and Feta cheeses whereby the mean scores for appearance, body and texture, flavor, and overall quality (total score) of cheeses salted with the $\mathrm{NaCl} / \mathrm{KCl}$ mixtures were not significantly different from those of the control cheese at all sampling ages (Katsiari et al., 1997, 1998).

\section{CONCLUSIONS}

No differences in acceptability were found between different salt treatments despite minor differences in descriptive analysis. These sensory results, coupled with the chemical and microbiological results, suggest that Halloumi cheese could be successfully manufactured using $\mathrm{NaCl} / \mathrm{KCl}$ brine instead of the commercial $\mathrm{NaCl}$ brine currently used in the cheese industry. This is especially true at lower brine concentrations, such as that used in this study, and at lower $\mathrm{NaCl}$ substitution percentages. It would be also interesting to study the effect of additional ingredients on the perceived bitterness and of using ingredients that would assist in masking this bitterness and thus improving the acceptability of Halloumi. The effect of the salt substitution needs

Table 13. Least squares means of fermented and milky flavor attributes of Halloumi samples (rated on a 15-cm line scale) for the salt treatment ${ }^{1}$ $\times$ age of cheese $(0$ to $8 \mathrm{wk})$ interaction $(\mathrm{ST} \times \mathrm{AC})$

\begin{tabular}{|c|c|c|c|c|c|c|c|c|c|c|c|c|}
\hline Flavor & \multicolumn{3}{|c|}{$0 \mathrm{wk}$} & \multicolumn{3}{|c|}{$2 \mathrm{wk}$} & \multicolumn{3}{|c|}{$4 \mathrm{wk}$} & \multicolumn{3}{|c|}{$8 \mathrm{wk}$} \\
\hline Fermented & $5.29^{\mathrm{bf}}$ & $5.19^{\mathrm{b}}$ & $5.56^{\text {bdef }}$ & $5.94^{\text {bdef }}$ & $7.04^{\mathrm{af}}$ & $5.97^{\text {bdef }}$ & $6.77^{\text {bcdef }}$ & $8.58^{\mathrm{a}}$ & $5.07^{\mathrm{b}}$ & $7.33^{\mathrm{ad}}$ & $7.88^{\mathrm{ac}}$ & $7.29^{\mathrm{ae}}$ \\
\hline
\end{tabular}

${ }^{\mathrm{a}-\mathrm{f}}$ Means within a salt treatment or age of cheese and within a row with different superscripts are significantly different $(P<0.05)$.

${ }^{1}$ Salt treatments: $\mathrm{A}=100 \% \mathrm{NaCl}$ (control); $\mathrm{B}=70 \% \mathrm{NaCl}, 30 \% \mathrm{KCl} ; \mathrm{C}=50 \% \mathrm{NaCl}, 50 \% \mathrm{KCl}$. 
Table 14. Significance of the effects ( $F$-values) of salt treatment and panelist on acceptability of Halloumi samples and least squares means of the acceptability scores (rated on a 9-point category hedonic scale) of Halloumi samples for the 3 salt treatments

\begin{tabular}{lccccccc}
\hline & \multicolumn{3}{c}{ Effect } & & \multicolumn{3}{c}{ Salt treatment $^{1}$} \\
\cline { 2 - 3 } \cline { 5 - 7 } Acceptability & $\begin{array}{c}\text { Salt treatment } \\
(\mathrm{df}=2)\end{array}$ & $\begin{array}{c}\text { Panelist } \\
(\mathrm{df}=71)\end{array}$ & & $\mathrm{A}$ & $\mathrm{B}$ & $\mathrm{C}$ \\
\hline Appearance & 1.50 & $4.84^{* * *}$ & & 6.42 & 6.47 & 6.15 \\
Flavor & 1.49 & $3.23^{* * *}$ & & 6.46 & 6.19 & 6.01 \\
Texture & 2.30 & $6.82^{* * *}$ & & 6.14 & 5.94 & 5.69 \\
Overall acceptability & 0.45 & $4.16^{* * *}$ & & 6.26 & 6.25 & 6.07 \\
\hline
\end{tabular}

${ }^{1}$ Salt treatments: $\mathrm{A}=100 \% \mathrm{NaCl}$ (control); $\mathrm{B}=70 \% \mathrm{NaCl}, 30 \% \mathrm{KCl} ; \mathrm{C}=50 \% \mathrm{NaCl}, 50 \% \mathrm{KCl}$.

$* * * P<0.001$.

to be investigated in other cheeses with different flavor profiles. Additional studies on the shelf life of products similar to those studied here are needed, especially if the products are to be packaged and potentially subjected to temperature abuse. The issue of potassium intake of products that have $\mathrm{KCl}$ substitution is of crucial importance from a public health perspective and needs to be further investigated.

\section{ACKNOWLEDGMENTS}

The authors thank Omar Kebbe Baghdadi and Darine Barakat (Nutrition and Food Sciences Department, Faculty of Agricultural and Food Sciences, American University of Beirut, Beirut, Lebanon) for their technical support. The financial support by the National Council for Scientific Research (CNRS, Lebanon) is gratefully acknowledged.

\section{REFERENCES}

Al-Otaibi, M. M., and A. Wilbey. 2006. Effect of chymosin reduction and salt substitution on the properties of white salted cheese. Int. Dairy J. 16:903-909.

Alichanidis, E., and A. Polychroniadou. 2008. Characteristics of major traditional regional cheese varieties of East-Mediterranean countries: A review. Dairy Sci. Technol. 88:495-510.

Aly, M. E. 1995. An attempt for producing low-sodium Feta-type cheese. Food Chem. 52:295-299.

Anjan Reddy, K., and E. R. Marth. 1995. Lactic acid bacteria in Cheddar cheese made with sodium chloride, potassium chloride or mixtures of the two salts. J. Food Prot. 58:62-69.

AOAC. 2000. Official Methods of Analysis. Vol. II. 17th ed. Association of Official Analytical Chemists International, Gaithersburg, MD.

Ayyash, M. M., and N. P. Shah. 2010. Effect of partial substitution of $\mathrm{NaCl}$ with $\mathrm{KCl}$ on Halloumi cheese during storage: Chemical composition, lactic bacterial count, and organic acids production. J. Food Sci. 75:C525-C529.

Ayyash, M. M., and N. P. Shah. 2011a. Effect of partial substitution of $\mathrm{NaCl}$ with $\mathrm{KCl}$ on proteolysis of Halloumi cheese. J. Food Sci. 76:C31-C37.

Ayyash, M. M., and N. P. Shah. 2011b. Proteolysis of low-moisture Mozzarella cheese as affected by substitution of $\mathrm{NaCl}$ with $\mathrm{KCl}$. J. Dairy Sci. 94:3769-3777.
Ayyash, M. M., and N. P. Shah. 2011c. The effect of substitution of $\mathrm{NaCl}$ with $\mathrm{KCl}$ on chemical composition and functional properties of low-moisture Mozzarella cheese. J. Dairy Sci. 94:3761-3768.

Ayyash, M. M., M. F. Sherkat, P. Francis, R. P. W. Williams, and N. P. Shah. 2011. The effect of sodium chloride substitution with potassium chloride on texture profile and microstructure of Halloumi cheese. J. Dairy Sci. 94:37-42.

Brady, M. 2002. Sodium - Survey of the usage and functionality of salt as an ingredient in UK manufactured food products. Br. Food J. 10:84-125.

Demirci, M. 1988. Ulkemizin önemli peynir çeşitlerinin mineral madde düzeyi ve kalori değerleri. Gıda 13:17-21.

Doyle, M. E., and K. A. Glass. 2010. Sodium reduction and its effect on food safety, food quality, and human health. Comp. Rev. Food Sci. Food Safety 9:44-56.

Faverotto, L. G. 1990. Investigation of trace element content of cheese. Food Addit. Contam. 7:425-432.

Fleet, G. 1990. Yeasts in dairy products. J. Appl. Bacteriol. 68:199211.

Gibson, J., G. Armastrong, and H. McIlveen. 2000. A case for reducing salt in processed foods. Nutr. Food Sci. 30:167-173.

Guinard, J.-X., and M. Cliff. 1987. Descriptive analysis of Pinot noir wines from Carneros, Napa, and Sonoma. Am. J. Enol. Vitic. $38: 211-215$.

Guinard, J.-X., D. Yip, E. M. Cubero, and R. Mazzucchelli. 1999 Quality ratings by experts, and relation with descriptive analysis ratings: A case study with beer. Food Qual. Prefer. 10:59-67.

Hannedouche, T., D. Bazin, and T. Krummel. 2007. Salt, hypertension, and public health. Nephrol. Ther. 3:S99-103.

Irkin, R. 2010. Determination of microbial contamination sources for use in quality management of cheese industry: "Dil" cheese as an example. J. Consum. Prot. Food Safety 5:91-96.

Kaminarides, S., P. Stamou, and T. Massouras. 2007. Changes of organic acids, volatile aroma compounds and sensory characteristics of Halloumi cheese kept in brine. Food Chem. 100:219-225.

Karagözlü, C., Ö. Kinik, and N. Abkulut. 2008. Effects of fully and partial substitution of $\mathrm{NaCl}$ by $\mathrm{KCl}$ on physico-chemical and sensory properties of white pickled cheese. Int. J. Food Sci. Nutr. 59:181-191.

Katsiari, M. C., E. Alichanidis, L. P. Voutsinas, and I. G. Roussis. 2001. Proteolysis in reduced sodium Kefalograviera cheese made by partial replacement of $\mathrm{NaCl}$ with $\mathrm{KCl}$. Food Chem. 73:31-43.

Katsiari, M. C., L. P. Voutsinas, E. Alichanidis, and I. G. Roussis. 1997. Reduction of sodium content in Feta cheese by partial substitution of $\mathrm{NaCl}$ by KCl. Int. Dairy J. 7:465-472.

Katsiari, M. C., L. P. Voutsinas, E. Alichanidis, and I. G. Roussis. 1998. Manufacture of Kefalograviera cheese with less sodium by partial replacement of $\mathrm{NaCl}$ with $\mathrm{KCl}$. Food Chem. 61:63-70.

Katsiari, M. C., L. P. Voutsinas, E. Alichanidis, and I. G. Roussis 2000. Lipolysis in reduced sodium Feta cheese made by partial substitution of $\mathrm{NaCl}$ by KCl. Int. Dairy J. 10:369-373.

Kilcast, D., and F. Angus. 2007. Reducing Salt in Foods-Practical Strategies. CRC Press, Boca Raton, FL. 
Kursun, O., S. S. Kirdar, E. Keyvan, and A. Guner. 2011. Microbiological quality of white pickled cheese produced in small plants in Burdur, Turkey. J. Food Agric. Environ. 9:110-112.

Leroy, F., and L. De Vuyst. 2004. Lactic acid bacteria as functional starter cultures for the food fermentation. Trends Food Sci. Technol. 15:67-78.

Litopoulou-Tzanetaki, E., and N. Tzanetakis. 1992. Microbiological study of white-brined cheese made from raw goat milk. Food Microbiol. 9:13-19.

Macfie, H. J., and N. Bratchell. 1989. Designs to balance the effect of order of presentation and first order carry over effects in hall tests. J. Sens. Stud. 4:129-148.

Manolopoulou, E., P. Sarantinopoulos, E. Zoidou, A. Aktypis, E. Moschopoulou, I. G. Kandarakis, and E. M. Anifantakis. 2003. Evolution of microbial populations during traditional Feta cheese manufacture and ripening. Int. J. Food Microbiol. 82:153-161.

Marshall, T. R., ed. 1993. Standard Methods for the Examination of Dairy Products. 16th ed. Am. Publ. Health Assoc. Inc., Washington, DC.

Milci, S., Z. Goncu, Z. Alpkent, and H. Yaygin. 2005. Chemical, microbiological and sensory characterization of Halloumi cheese produced from ovine, caprine and bovine milk. Int. Dairy J. 15:625630

Olson, N. F. 1990. The impact of lactic acid bacteria on cheese flavor. FEMS Microbiol. Lett. 47:131-147.
Öner, Z., A. G. Karahan, and H. Aloğlu. 2006. Changes in the microbiological and chemical characteristics of an artisanal Turkish white cheese during ripening. Lebenson. Wiss. Technol. 39:449-454.

Papademas, P. 2006. Halloumi cheese. Pages 117-138 in Brined Cheeses. A.Y. Tamime, ed. Blackwell, Oxford, UK.

Papademas, P., and K. Robinson. 2001. The sensory characteristics of different types of Halloumi cheese as perceived by tasters of different ages. Int. J. Dairy Technol. 54:94-99.

Papademas, P., and R. A. Robinson. 2000. Comparison of the chemical, microbiological and sensory characteristics of bovine and ovine Halloumi cheese. Int. Dairy J. 10:761-768.

Papaioannou, G., I. Chouliara, A. E. Karatapanis, M. G. Kontominas, and I. N. Savvaidis. 2007. Shelf-life of a Greek whey cheese under modified atmosphere packaging. Int. Dairy J. 17:358-364.

Peryam, D. R., and F. J. Pilgrim. 1957. Hedonic scale method of measuring food preferences. Food Technol. 11:9-14.

Sihufe, G. A., S. E. Zorrilla, and A. C. Rubiolo. 2006. Secondary proteolysis of Fynbo cheese salted with $\mathrm{NaCl} / \mathrm{KCl}$ brine and ripened at various temperatures. Food Chem. 96:297-303.

Turantas, F., A. Ünlütürk, and D. Göktan. 1989. Microbiological and compositional status of Turkish white cheese. Int. J. Food Microbiol. 8:19-24. 